\title{
AL-A'RAF
}

Jurnal Pemikiran Islam dan Filsafat

\section{ANNA M. GADE DAN MTQ DI INDONESIA: SEBUAH KAJIAN METODOLOGIS}

\author{
Nur Rohman \\ Alumni Prodi Agama dan Filsafat, Pascasarjana UIN Sunan Kalijaga, \\ Yogyakarta
}

\begin{tabular}{|c|c|}
\hline & Abstrak \\
\hline $\begin{array}{l}\text { Keywords: } \\
\text { Orientalis, } \\
\text { Qur'anic } \\
\text { studies, Socio- } \\
\text { Anthropological } \\
\text { approach }\end{array}$ & $\begin{array}{l}\text { Tulisan ini merupakan upaya pembacaan ulang terhadap penelitian } \\
\text { orientalis yang meneliti tentang praktik pembacaan Alqur'an di } \\
\text { Indonesia. Pembacaan terhadap karya ini penting, utamanya terkait } \\
\text { dengan metodologi yang dipakai, karena pada saat bersamaan para } \\
\text { peminat kajian Alqur'an dan budayawan melihat berbagai aktifitas } \\
\text { sehari-hari masyarakat menunjukkan adanya gejala alamiah yang } \\
\text { dapat didekati dengan disiplin keilmuan sosial-humaniora. Dalam } \\
\text { tulisan ini dijelaskan bahwa Anna Gade mengoperasikan teori } \\
\text { Clifford Geertz tentang agama sebagai sistem kebudayaan. Anna } \\
\text { Gade mengatakan bahwa praktik pembacaan Alqur'an didasari } \\
\text { oleh beberapa hal, yang kemudian dikelompokkan ke dalam mood } \\
\text { and motivation. }\end{array}$ \\
\hline
\end{tabular}

\begin{abstract}
This article constitutes to repeatedly reading the orientalist's research findings on the practice of the holy Qur'an's reading in Indonesia. It is very important, especially related to the methodology used, because at the same time both of those who are interested to study the holy Qur'an and the cultural observers see the various daily activities of the people showing the natural phenomenon that can be approached through the social-humanities disciplines. This article explained that Anna M. Gade operated Clifford Geertz's theory on religion as cultural system. Anna Gade said that the practical reading of the Qur'an (in Indonesia) is constituted by several things, which then grouped into motivation and mood.
\end{abstract}




\section{Pendahuluan}

Perbincangan seputar orientalis dan metodologi yang dipakai dalam mengkaji Alqur'an pada masa kontemporer, Sahiron membaginya ke dalam tiga kategori; ${ }^{1}$ Pertama, pendekatan historis-kritis yang bertujuan menentukan secara historis objek sebenarnya dari penelitian (Alqur'an). Kedua, pendekatan interpretatif yang menganggap teks Alqur'an sebagai teks final dan perlu ditafsirkan. Ketiga, pendekatan deskriptif sosioantropologis, di mana penelitian yang dilakukan memfokuskan kajiannya ke arah penerimaan (reception) masyarakat muslim terhadap Al-qur'an.

Hal di atas sejalan dengan pemetaan yang dilakukan oleh Nur Kholis Setiawan atas karya-karya para orientalis terkait kajian Al-qur'an, yang secara garis dibaginya ke dalam tiga kelompok besar. ${ }^{2}$ Pertama, kajian yang terarah pada kajian teks kitab suci. Kajian ini terkait erat dengan pendekatan kritik sejarah (bistorical criticism). Nama-nama seperti Abraham Geiger, John Wansbrough, Theodore Noldeke, John Burton, masuk dalam kategori ini. Kedua, alih bahasa Al-qur'an. Kategori ini menggunakan pendekatan interpretatif dalam kajiannya. Kelompok kategori ini beranggapan bahwa teks Alqur'an telah final pembahasan terkait dengan otentisitas dan keasliannya, namun perlu ditafsirkan. Sehingga diperlukan metodologi tertentu, sebagaimana dilakukan oleh Daniel Madigan dengan semantic analysis. Ketiga, karya yang terkonsentrasi pada bagaimana umat Islam memahai Al-qur'an. Pada bagian ini, digun akanlah pendekatan antropologis-sosiologis—sebagaimana disebut Sahiron di atas. Artinya, tidak hanya ilmu antropologi saja yang digunakan, tapi juga ilmu-ilmu yang berkaitan seperti sosiologi dan atau lainnya.

${ }^{1}$ Sahiron Syamsuddin, "Pendekatan Orientalis dalam Studi Alqur'an", dalam Moch Nur Ichwan dan Ahmad Muttaqien, Islam, Agama-agama. dan Nilai Kemanusiaan; Festschrift untuk. Amin Abdullah (Yogyakarta: CISForm, 2013), 95-109.

${ }^{2}$ Nur Kholis Setiawan, “Orientalisme Alqur'an: Dulu, Kini dan Masa Datang”, dalam Sahiron Syamsuddin dan Nur Kholis Setiawan (ed.), Orientalisme Alqur'an dan Hadith (Yogyakarta: Nawesea Press, 2007), 1. 
Pendapat di atas, sedikit banyak telah memengaruhi beberapa sarjana di Indonesia dalam melihat fenomena yang terjadi pada masyarakat Indonesia, terkait dengan cara orang memperlakukan Al-qur'an. Beberapa fenomena yang terjadi, kemudian dipahami sebagai upaya masyarakat dalam menghidupkan Alqur'an dalam kehidupan sehari-hari dengan ragam cara dan bentuk, yang sering disebut dengan istilah "The Living Qur'an". Oleh sebab itulah maka para pegiat kajian Alqur'an pun merumuskan beberapa sudut pandang untuk mengkajinya. Setidaknya ada tiga sudat pandang dalam kajian ini: resepsi hermeneutik (hermeneutics' reception), resepsi kultural (cultural reception), dan resepsi estetis (esthetical reception). ${ }^{3}$

Berdasarkan pada pemetaan di atas, tulisan ini akan memfokuskan pada karya orientalis yang pokok penelitiannya terkait pada masalah pemahaman umat Islam terhadap Alqur'an yang ada di Indonesia. Salah satunya adalah Anna Gade, yang melakukan kajian terhadap praktik pembacaan Alqur'an dan pola pengajarannya di Indonesia yang telah diterbitkan pada tahun 2004, dengan judul "Perfection Makes Practise". Salah satu isu yang menjadi sorotan penting Anna Gade adalah Musabaqob Tilawati Alqur'an (MTQ) atau lomba membaca Alqur'an yang telah menjadi agenda rutin di Indonesia. MTQ sendiri telah mendapat tempat dalam masyarakat Indonesia, khususnya pesantren dan beberapa lembaga yang fokus pada pembelajaran Alqur'an.

Kajian yang dilakukan Anna Gade tersebut sangat perlu untuk dibaca dan dijadikan bahan pertimbangan, khususnya bagi para peminat kajian Alqur'an dan dinamikanya di Indonesia. Sebab disamping telah menjadi agenda rutin, MTQ juga mampu mendorong lahirnya gejala-gejala sosial lain. Bahkan praktek pembacaan Alqur'an dengan nada dan suara indah, saat ini telah menjadi kebutuhan masyarakat muslim. Selain itu, penelitian Gade juga memberikan kontribusi penting dalam hal metodologi penelitian, khususnya terkait dengan wacana menghidupkan Alqur'an di masyarakat

${ }^{3}$ Lebih lanjut tentang Living Qur'an, baca. M. Mansyur dkk., Metodologi Penelitan Living Qur'an dan Hadith (Yogyakarta: TH Press, 2007). 
(The Living Qur'an). Aspek metodologis yang dibangun Anna Gade dalam bukunya "Perfection Makes Practice", 4 diharapkan dapat menjadi sumbangan model penelitian dalam pengembangan kajian Living Qur'an di Indonesia.

\section{Anna M. Gade dan Pencariannya}

Anna M. Gade adalah seorang professor dengan banyak prestasi di Universitas Wisconsin, Madison, pada Institut Nelson yang concern di bidang Environmental Studies (Studi tentang Lingkungan). Ia memperoleh gelar M.A. dan Ph.D. dari Universitas Chicago (Chicago University) di bidang sejarah agama-agama (The History of Religions) dengan spesialisasi tentang Islam. Sedangkan gelar B.A. diperolehnya dari Swarthmore College di bidang Matematika. $^{5}$

Anna Gade memperoleh banyak jabatan akademik di beberapa lembaga, diantaranya Cornell University pada kajian Timur (Near Eastern Studies), Princeton University pada bidang kajian musik dan agama (Music and Religion), bidang agama (Disciplin of Religion) di Oberlin College, kajian agama (Religious Studies) di Victoria University of Wellington, New Zealand, serta bidang bahasa dan budaya Asia (Languages and Cultures of Asia) di UW-Madison. ${ }^{6}$

Anna Gade banyak melakukan penelitian yang menekankan pada aspek teori dan metodologi dalam disiplin akademik, khusunya di bidang agama dan studi Islam. Beberapa karyanya mengulas tentang kebudayaan global (global culture), sejarah, dan respon agama terhadap perubahan lingkungan. Khususnya lagi dalam sejarah, pengetahuan, dan praktekpraktek yang ada di Asia Tenggara. Pada penelitian sebelumnya, ia melakukan penelitian lapangan yang cukup luas di Indonesia, Kamboja, dan Malaysia. Anna Gade juga mengajar pada beberapa wilayah cakupan

${ }^{4}$ Anna M. Gade, Perfection Makes Practice; Lerning, Emotion, and The Recited Qur'an in Indonesia (USA: Hawai Press, 2004).

${ }^{5}$ Diakses dari. www.islamicstudies.harvard.edu. (11 Mei 2016).

${ }^{6}$ Lihat. sites.google.com/a/wisc.edu/amgade. 
disiplin akademik, seperti Studi Islam dan Keislaman, Studi Agama Global, Studi Asia, dan Komparasi antara Etika Lingkungan dan Studi Lingkungan yang dikaji melalu persepsi manusia.?

Terkait penelitiannya tentang Qur'an Recitation in Indonesia, Anna Gade memulai dengan menjelaskan tentang perkembangan pembelajaran Alqur'an di Indonesia. Fenomena yang ia dapatkan di Indonesia adalah bahwa minat belajar Alqur'an masyarakat muslim Indonesia sangat tinggi. Hal itu terlihat dari mereka yang mempelajari Alqur'an tidak hanya dilakukan oleh kalangan muda, tapi juga dari kaum dewasa dan tua. Selain itu, media pembelajaran Alqur'an di Indonesia pun sangat beragam. Di Makassar misalnya, pembelajaran Alqur'an lewat radio dalam acara "bimbingan tadarusan Al-qur'an", mendengar kaset-kaset pengajian dan lain-lain. ${ }^{8}$ Inilah yang kemudian menjadi satu keunikan tersendiri, sebab masyarakat Indonesia sebagai masyarakat muslim terbesar di dunia, 80 persen penduduknya tidak begitu mengerti bahasa Arab, tapi semangatnya tinggi dalam mempelajari dan membaca Alqur'an. Sehingga menarik untuk diteliti mengapa dan apa motivasi dibalik itu.

Selain itu, Anna Gade juga memfokuskan kajiannya di wilayah Sulawesi Tenggara, dengan pertimbangan bahwa Makassar merupakan salah satu kota di Indonesia dengan tingkat semarak yang tinggi dalam tradisi-tradisi Alqur'an, yang dibentuk secara kelembagaan, seperti masjid Al-Markaz Al-Islami sebagai Yayasan Islamic Center. Di Yayasan ini dibentuk satu lembaga khusus yang menangani pengajaran Alqur'an, mulai dari pemula sampai yang sudah mahir.'

\section{Sekilas tentang MTQ di Indonesia}

Melacak asal-usul MTQ di Indonesia, tidak bisa dipisahkan dari studi tentang sejarah Islam di Indonesia. Federspiel, sebagaimana dikutip

\footnotetext{
${ }^{7}$ sites.google.com/a/wisc.edu/amgade. (diakses pada 11 Mei 2016).

${ }^{8}$ Anna M. Gade. Perfection Makes Practice., 7

${ }^{9}$ Anna M. Gade. Perfection Makes Practice., 7.
} 
Iskandar, menyebutkan bahwa di kalangan umat Islam Indonesia terdapat perhatian besar dalam praktik membaca Alqur'an. Anak-anak belajar Alqur'an sebagai bagian dari pendidikan agama, dan para anggota keluarga sesekali akan membaca Alqur'an bersama di rumah sebagai tanda ketaatan dalam beragama. Pernyataan tersebut membuktikan bahwa membaca Alqur'an, merupakan bagian dari kultur masyarakat di Indonesia, dan tradisi ini telah berlangsung sejak masuknya Islam di Indonesia yang dibawa oleh para misionaris Islam kala itu. ${ }^{10}$

Terbentuknya MTQ di Indonesia, tidak dapat dipisahkan dari pengaruh dua kutub besar Timur Tengah, Mekkah dan Mesir. Mengingat banyaknya kaum muda Indonesia yang menimba ilmu di sana. Sepulangnya dari sana, mereka pun banyak yang kemudian menjadi kyai, ustadz, dan mengembangkan ilmu keislamannya di Indonesia. Salah satunya adalah membaca Alqur'an dengan 'langgam' yang mereka peroleh selama di Mekkah dan Mesir. Inilah yang kemudian dinisbatkan dengan langgam Makkawi dan Mishri. ${ }^{11}$

Menurut catatan sejarah, MTQ telah ada di Indonesia sejak tahun 1940-an, sejak berdirinya Jami'iyyatul Qurro' wa al-Huffadzyang didirikan oleh Nahdlatul Ulama, sebagai ormas terbesar di Indonesia. Sejak tahun 1968, saat Menteri Agama Republik Indonesia dijabat K.H. Muhammad Dahlan MTQ dilembagakan secara nasional. MTQ pertama diselenggarakan di Makassar pada bulan Ramadan tahun 1968. Kala itu hanya melombakan tilawah dewasa saja, dan melahirkan qari' Ahmad Syahid dari Jawa Barat serta Muhammadong dari Sulawesi Selatan. MTQ kedua diselenggarakan di Banjarmasin tahun 1969, dan ketiga pada tahun 1970 di Jakarta. ${ }^{12}$

Penyelenggaraan dan perkembangan MTQ di Indonesia tidak bisa dilepaskan dari peran beberapa qari’ terkenal di Indonesia, seperti K.H.

${ }^{10}$ Syahrullah Iskandar, "MTQ dan Negara; Sebuah Tinjauan Hegemonik", dalam Irwan Abdullah, dkk. (ed.), Dialektika Teks Suci Agama (Yogyakarta: Sekolah Pasca Sarjana UGM, 2008), 245. Pernyataan ini juga dapat dilihat pada Azyumardi Azra, Jaringan Ulama Timur Tengah dan Kepulauan Nusantara Abad XVII dan XVIII (Bandung: Mizan, 1998), 31.

${ }^{11}$ Syahrullah Iskandar, MTQ dan Negara; Sebuah Tinjauan Hegemonik, 256.

${ }^{12}$ Diakses dari (http://id.wikipedia.org/). 
Aziz Muslim, K.H. Bashori Alwi, Hj. Rofiqoh Darto Wahab, Hj. Nursiah Ismail, Hj. Aminah, Hj. Maria Ulfah, Muammar ZA, Muhammadong, Muhammad Ali, H. Wan Muhammad Ridwan Al-Jufrie', dan lain sebagainya. Di antara qari' tersebut, Maria Ulfa, ${ }^{13}$ turut memberikan andil besar terhadap penelitian Anna Gade ini.

Seiring perkembanganya, MTQ mengalami perbaikan dan antusiasme masyarakat pun semakin tinggi untuk mengikutinya. Sehingga semakin banyak dan sering diselenggarakan. MTQ bukan lagi menjadi sebuah klaim dari satu institusi, karena sudah berkembang dan dimiliki oleh berbagai lembaga, baik negeri ataupun swasta sebagai penyelenggaranya.

\section{Antropologi sebagai Pendekatan Penelitian}

Salah satu poin penting dalam tulisan ini adalah menyoroti aspek metodologi yang dipakai Anna Gade dalam melihat praktek pembacaan Alqur'an di Indonesia, khususnya di Sulawesi Tenggara. Penelitian Anna Gade ini tidak hanya didapat dari sumber-sumber lapangan (field research), tapi juga didukung oleh data library atau tulisan Arab klasik seperti tulisan Al-Ghazali. Karena itu penelitian ini lebih cenderung kepada pendekatan etnografis. ${ }^{14}$

Selain itu, dalam banyak hal Anna Gade juga menyebut penggunaan teori Geertz. Anna Gade memaparkan konsep 'agama' menurut Geertz, ${ }^{15}$ yaitu (1) satu sistem simbol yang bertujuan untuk (2) menciptakan

${ }^{13}$ Seorang qari' wanita yang menurut Anne Rasmussen merupakan sesuatu yang unik dan yang membedakan antara pembacaan Alqur'an di ranah publik, antara Indonesia dan negara Timur Tengah. Selain menginspirasi Anna Gade, Anne Rasmusen juga berterima kasih banyak terhadap Maria Ulfa, karena informasi dalam penelitiannya banyak digali dari Maria Ulfa sendiri. Selengkapnya lihat. Anne Rasmussen, Women, The Recited Qur'an, and Islamic Music in Indonesia (London: University of California, 2010).

${ }^{14}$ Koentjaraningrat, Pengantar Ilmu Antroplogi (Jakarta: Rineka Cipta, 2009), 37.

15 "(1) A system of symbols which act to (2) establish powerful, pervasive, and long lasting moods and motivations in men by (3) formulating conceptions of a general order of existence and (4) clothing these conceptions which such an aura of factuality that (5)the moods and motivations seem uniquely realistic". Lihat. Anna M. Gade, Perfection Makes Practice; Lerning, Emotion, and The Recited Qur'an in Indonesia (USA: Hawai Press, 2004), 51. 
perasaan dan motivasi yang kuat (moods and motivations), mudah menyebar, dan tidak mudah hilang dalam diri seseorang, (3) dengan cara membentuk konsepsi tentang sebuah tatanan umum eksistensi, dan (4) melekatkan konsepsi tentang sebuah tatanan faktual, (5) dan pada akhirnya perasaan dan motifasi ini akan terlihat sebagai suatu realitas yang unik.

Dalam konteks ini, Geertz sebagaimana dikutip oleh Anna Gade menjelaskan lebih lanjut tentang konsep teori tersebut, ${ }^{16}$ bahwa "sebuah sistem simbol" adalah segala sesuatu yang memberi seseorang ide-ide, yang itu bukanlah milik pribadi tapi miliki publik, yang merupakan sesuatu di luar diri manusia. Dikatakan bahwa simbol-simbol tersebut "menciptakan perasaan dan motivasi yang kuat (moods and motivations), mudah menyebar, dan tidak mudah hilang dalam diri seseorang", Geertz menjelaskan bahwa agama menyebabkan seseorang merasakan atau melakukan sesuatu. Motivasi tentu memiliki tujuan tertentu, dan orang yang termotivasi akan dibimbing oleh seperangkat nilai tentang apa yang penting, apa yang baik dan buruk, apa yang benar dan salah bagi dirinya.

Dari sinilah Anna Gade mencoba mengungkap makna dibalik simbol-simbol dari praktik pembacaan Alqur'an di Indonesia, seperti pada praktik MTQ, ragam bacaan Alqur'an, dan model pembelajaran Alqur'an, sangat berkaitan erat dengan moods and motivations dari masyarakat muslim Indonesia. Selain itu, seorang pengahafal Alqur'an pun memiliki prestige tersendiri dibanding masyarakat biasa (bukan penghafal Alqur'an). Ia dianggap memiliki nilai lebih dibanding lainnya, terutama dalam hal kesalehan. Keadaan inilah yang turut menumbuhkan mood and motivation di kalangan masyarakat muslim Indonesia. Dari kacamata inilah Anna Gade memaparkan lebih lanjut tentang mood and motivations yang terjadi dalam proses pembacaan Alqur'an di Indonesia.

${ }^{16}$ Penjelasan tentang konsep ini juga bisa dilihat dalam Clifford Geertz, 'Agama Sebagai Sistem kebudayaan', dalam Daniel L. Pals (ed.), Seven Theories of Religion, terj. Inya Indza Mundzier (Yogyakarta: IRCiSod, t.th), 342-344. Lihat juga pada David N. Gellner, "Pendekatan Antropologis" dalam Peter Connolly (ed.), Aneka Pendekatan Studi Agama, terj. Imam Khoiri (Yogyakarta: LKiS, 2012). 


\section{Ekspresi, Emosi dan Pendidikan}

Dalam pembahasan ini Anna Gade menjelaskan bahwa usaha untuk membaca Alqur'an dengan seni yang khas, itu menciptakan potensi yang dimiliki oleh individu dan meningkatan kesadaran relijiusnya. Setidaknya ada tiga aspek yang ditemukan dalam dunia pembacaan Alqur'an di Indonesia sekitar tahun 1990-an untuk menghasilkan perluasan orthopraxy, ${ }^{17}$ yang difasilitasi oleh kesadaran diri para pendidik dan strategi sosial. ${ }^{18}$ Pertama, persepsi tentang kualitas yang "tertutup" dari sistem pembacaan Alqur'an, yang didasarkan pada doktrin i'ja\%, harapan dari sebuah praktik yang baik, dan tendesi untuk membayangan kompetensi sebagai sesuatu yang tetap dan stabil. Artinya, pemahaman tentang Alqur'an merupakan sesuatu yang telah baku dan telah ditentukan dalam pembacaannya. Itulah sebabnya, Anna Gade memilih redaksi terhadap persepsi ini dengan kata "closedness" (tertutup). Selain itu, Gade menjelaskan bahwa sistem dari praktek Alqur'an yang pertamakali ditawarkan untuk para penghafal, pembaca, dan pelantun memiliki rasa dari sebuah horizon yang telah ditetapkan, didukung oleh dinamika yang terulang-ulang, yang menghasilkan harapan secara menyeluruh dari ketetapan dan penutupan.

Jika yang pertama adalah sesuatu yang tertutup dalam sistem ijjaz: Artinya mushaf yang ada telah tertutup pengembangannya, dan orang yang membacanya di bawah naungan i'jaz akan mendapatkan pahala karena Alqur'an merupakan mu'jizat yang telah diyakini. Aspek yang kedua adalah dalam proses pembelajaran. Artinye, mushaf mempunyai "keterbukaan" dari normativitas standar yang ada di dalam musikalisasinya, seperti 'keindahan', 'perasaan', dan 'improvisasi' telah mampu mengembangkan formalisasi dan pengembangan di dalam pengajaran dan pembelajaran. Beberapa unsur fleksibilitas yang telah ditetapkan dalam sistem pengajaran dan pembelajaran telah dikombinasikan dengan aspek-aspek pembelajaran

${ }^{17}$ Anna Gade menjelaskan, bahwa Orthopraxy is mode of evaluation based on shared norms, which may also be experienced as a feeling-state.

${ }^{18}$ Anna M. Gade, Perfection Makes Practice, 168. 
yang efektif untuk menghasilkan kualitas yang dapat diperluas, sehingga pembaca yang secara aktual dapat memperoleh cakrawala 'kompetensi' dan 'orthopraksi.'19

Dalam proses melantunkan Alqur'an, ada keterbukaan di dalam memperindah dan mengembangkan bacaan. Oleh karena itu di Indonesia, model bacaan atau lagu mengalami beberapa perkembangan. Ada dua lagu (sistem bacaan mujawwad) yang terkenal, yaitu Makawi $i^{20}$ dan Misri. ${ }^{21}$

${ }^{19}$ Anna M. Gade, Perfection Makes Practice, 168.

${ }^{20}$ Kata Makkawi merupakan nisbat kepada kota Makkah. Lagu Makkawi adalah lagu-lagu yang tumbuh subur dan berkembang di Makkah. Menurut para ahli lagu, jumlah lagu Makkawi ada tujuh macam yang disingkat dan dihimpun dalam kalimat Bihamrin Jasadin, yang berarti 'jasad yang kemerah-merahan' disebabkan karena tujuh lagu itu dibawakan oleh qori dengan suara dan tangga nada yang lengkap hingga nada tinggi, atau biasa disebut dengan nada jawabul jawab. Lagu-lagu Makkawi tersebut adalah: Banjakah, Hiraab, Maya, Rakby, Jiharka, Sika, dan Dukkah. Lagu-lagu ini berkembang di Indonesia melalui ulama-ulama di Indonesia. Walaupun mayoritas masih dalam bentuk murattal untuk hafalan Alqur'an. Pada saat yang sama bermunculan qari'-qari' Indonesia yang menggunakan lagu Makkawi dalam bentuk mujawwad. Oleh karena itu, pada tahun 1950an telah dibentuk sebuah organisasi bernama Jam'iyyatu al-Qurra' wa al-Huffaz. (persatuan para Qari' dan Hafidh) yang berpusat di Surabaya, kemudian berpindah ke Jakarta. Berdirinya organisasi ini merupakan salah satu faktor yang melatarbelakangi tumbuh suburnya seni baca Alqur'an di Indonesia. Walaupun waktu itu kegiatannya belum mengarah pada musaabaqah, karena masih dititikberatkan pada pembinaan dan pengajaran membaca, menghafal, dan melagukan Alqur'an. Lihat. M. Husni Thamrin, Nadhom dalam Alqur'an; Telaab atas Kemunculan dan Perkembangan Nagham di Indonesia, (Yogyakarta: Tesis UIN Sunan Kalijaga, 2008), 72-73. Dalam hal ini, Anna Gade juga menjelaskan antara model pembacaan Makkawi, hanya saja tidak menjelaskan ketujuh model lagunya. Lihat. Anna M. Gade, Perfection Makes Practice, 183.

${ }^{21}$ Terhitung sejak tahun 1955-1960, pemerintah Mesir mengirimkan beberapa qori (syekh) ternama ke Indonesia dan ke beberapa negara Islam dalam rangka menyemarakkan bulan suci Ramadhan. Para qari' itu oleh menteri Agama diusahakan dapat disebarluaskan ke seluruh nusantara selama bulan Ramadhan. Setiap malam mereka membaca Alqur'an dengan lagu yang merdu dan memukau hadirin, berpindah dari satu kota ke kota lain sampai menjelang hari raya Idul Fitri. Inilah awal terjadinya revolusi lagu Alqur'an: dari Makkawi menjadi Misri. Para qari' Mesir yang pernah berkunjung dan dikirim ke Indonesia antara lain: syekh Abdul Basith Abdus Shamad, Syekh Thanthawi, Syekh Mahmud Mujahid, Syekh Musthafa Ismail, Syekh Mahmud khalil al-Husairi, Syekh Abd al-Hayy Zhahran, Syekh Abdul Qadir Abdul Azhim, Syekh Sa’id al-Syarief. Selain faktor kunjungan tersebut, adanya pengiriman qari' Indonesia ke ajang MTQ international yang diseleksi oleh para qari' tersebut telah menancapkan dominasi lagu Misri di Indonesia. Lagu Misri dari tujuh macam lagu yang sering disebut dengan bisabril jasad, yaitu: Bayyati, Hijaz, Shaba, Rast, Nahawan, Sika, dan Jibarkah. Lihat. M. Husni Thamrin, Nagham dalam 
Pada perkembangannya, lagu atau model bacaan Misri lebih berkembang daripada model Makkawi. Hal ini desebabkan beberapa faktor, diantaranya bahwa ada qari' yang merupakan utusan dari Mesir kemudian menjadi guru besar di Perguruan Tinggi Ilmu Alquran (PTIQ) Jakarta pada tahun 1974-1981. Para qari' Mesir itu membaca Alqur'an dengan lagu ala Mesir yang sangat merdu, sehingga berpengaruh kepada penjiwaan para qari' di Indonesia terhadap kandungan Alqur'an. Para qari' Indonesia yang tertarik dengan lagu-lagu ala Mesir, kemudian mempelajarinya serta berlatih hingga menguasainya. Selain itu, faktor lain yang menyebabkan berkembangnya model Misri adalah diadakannya beberapa musabaqoh, seperti MTQ di Konferensi Islam Asia Afirka, MTQ Nasional dan International, dan PTIQ. ${ }^{22}$

Kedua aspek di atas secara tidak langsung turut serta mendorong terjadinya praktek hafalan dan pembelajaran Alqur'an oleh lapisan masyarakat umum, sehingga pada akhirnya turut menyemarakkan proses perkembangan pembacaan Alqur'an di Indonesia. Sebagaimana dikatakan oleh Anna:

"An Interplay of these two dimensions sustained ordinary Indonesians practice in melodic recitation and also supported escalating engagement in many cases. In multiple domains of practice, there was a generative system in effect, based on the internal dynamics of the recited Qur'an and amplified and enhanced by the institution and discourses of particular social system. Effort to align expansive ideas with actual practice were the mechanism of inspiration for a widespread movement of Qur'anic revitalitation". ${ }^{23}$

Dari pernyataan di atas dapat dipahami bahwa ketiga aspek yang telah dijelaskan di atas, merupakan tiga aspek yang saling terkait dalam perkembangan pembacaan Alqur'an di Indonesia, baik dalam proses pembelajaran maupun dalam pembentukan sistem sosial masyarakat, khususnya dalam upaya perluasan revitalisasi Alqur'an.

Alqur'an, 74-75. Lihat juga. Anna M. Gade, Perfection Makes Practice, 183.

${ }^{22}$ M. Husni Thamrin, Nagham dalam Alqur'an, 76.

${ }^{23}$ Anna M. Gade, Perfection Makes Practice, 168. 


\section{Kompetisi: dari Promosi hingga Partisipasi}

Kontes pembacaan Alqur'an menggambarkan ekspresi pola pikir masyarakat Asia Tenggara dalam arus utama gerakan global, atau dalam bahasa Anna Gade disebut dengan "kebangkitan Islam" (islamic awakening). ${ }^{24}$ Fenomena kebangkitan yang terjadi di Indonesia lebih ditekankan lagi pada antusiasme mengembangkan seni Alqur'an, seperti dalam hal membaca dan menghafal. Masyarakat Muslim di Indonesia mengakui, bahwa mungkin ada ajakan tersirat untuk mencoba diri sendiri dalam keterbukaan dalam kerangka persaingan, penyampaian kata "motivasi" dari segi ketaqwaan, bahkan bagi mereka yang tidak ikut serta dalam persaingan sekalipun. Kompetisi dipahami sebagai bentuk pendidikan agama dan dakwah serta mempopulerkan keterlibatan Alquran di bawah label "pemuliaan Islam", atau Syiar Islam. Konseptualisasi ini menurun di kalangan para ahli agama, dengan menyoroti tujuan menyeluruh bahwa turnamen melahirkan "motivasi" untuk berpartisipasi dalam kegiatan-kegiatan Qur'ani dan ketakwaan. "Motivasi” ini akan membuat mereka melakukan latihan yang intensif, dan hal tersebut adalah obyek serta tujuan kerangka kompetisi. Melalui kompetisi, sistem latihan Alqur'an dikembangkan berdampingan dengan tujuan menanamkan minat dan keterlibatan kalangan muslim Indonesia pada 1990-an, yang didorong oleh partisipasi individu didasari oleh kemauan atau "motivasi” untuk berlatih, sebagai objek budidaya. ${ }^{25}$

Kompetisibacaan Alqur'anpopulerpada1990-anyangdisosialisasikan dalam bentuk khusus, dari gaya membaca dan praktik masyarakat muslim Indonesia secara luar biasa. Hal ini bertujuan membangun struktur agama dan sosial yang efektif. Turnamen tersebut meningkatkan motivasi untuk berlatih membaca Alqur'an, termasuk menghafal, kaligrafi, serta bacaan dalam gaya mujawwad. Kompetisi-kompetisi, terutama turnamen nasional, dipahami untuk mendorong masyarakat Muslim Indonesia untuk mempelajari bacaan Alqur'an, meskipun hanya menjadi inspirasi

\footnotetext{
${ }^{24}$ Anna M. Gade, Perfection Makes Practice, 216.

${ }^{25}$ Anna M. Gade, Perfection Makes Practice, 216.
} 
(mengagumi kemampuan orang lain dan menginginkan untuk menirunya), aspirasi (keinginan menang untuk pribadi atau kelompok, atau mungkin hadiah yang ditawarkan), dan partisipasi (tujuan itu sendiri). Dimensi praktek persaingan (tujuh standar jenis lagu atau melodi, misalnya) dipengaruhi bagaimana bacaan dipraktekkan secara keseluruhan, seperti dalam pertunjukan publik non-kompetisi. Nilai, standar, dan pengalaman yang muncul dari kompetisi bersamaan dengan kuantitas mereka yang berlatih kemudian disempurnakan secara efektif dengan komponen teknis dari praktik, meningkat di berbagai level, bahkan bagi mereka yang tidak bersaing sekalipun. Sistem tersebut kemudian diperluas dengan format dan evaluasi "orthoprax", dengan estetika dan teknik efektif, kemudian diadopsi dalam program yang semakin energik dalam hal kesalehan. ${ }^{26}$

Hal ini sejalan dengan yang disampaikan M. Quraish Shihab, bahwa tujuan diadakannya kompetisi (MTQ) dalam tataran hif $\not h$ dan aspek tafsir adalah menggairahkan dan menggalakkan generasi muda Islam untuk menghafal dan menafsirkan Alqur'an, mencetak ulama hafį̧̌ yang ahli dalam tafsir Alqur'an, dan mencari calon hafiæh dan mufassir terbaik untuk dikirim ke musabaqah tingkat international. ${ }^{27}$

Selain itu, pada dekade 1990-an, dengan keberadaan beberapa kompetisi (MTQ) telah membentuk suatu pengalaman tersendiri di kalangan umat Islam di Indonesia. Pengalaman inilah yang turut mempengaruhi pola sistem sosial dan penyelenggaraan MTQ berikutnya. Sehingga wajar jika pada setiap kompetisi (MTQ) ada perubahan gaya, metode, dan praktik penyelenggaraannya. Selain itu juga berpengaruh pada pelatih, kontestan, juri, dan sebagainya. ${ }^{28}$ Artinya, model kompetisi pembacaan Alqur'an (MTQ) tidaklah stagnan, terus mengalami perkembangan seiring pengalaman yang didapat. Pengalaman ini tidak hanya berpengaruh pada model kompetisi yang diselenggarakan, tetapi juga berpengaruh pada sistem masyarakat dan model pembelajaran Alqur'an.

\footnotetext{
${ }^{26}$ Anna M. Gade, Perfection Makes Practice, 217.

${ }^{27}$ M. Quraish Shihab, Membumikan Alqur'an (Bandung: Mizan, 2007), 189.

${ }^{28}$ Anna M. Gade, Perfection Makes Practice, 220.
} 
Pada perkembangannya, kompetisi (MTQ) tidak hanya menampilkan perlombaan dalam bidang pembacaan Alqur'an saja, tetapi juga cabang lain seperti Hif̨̌h Alqur'an, Tafsir Al-qur'an, Fabm Al-qur'an, Syarh Alqur'an, dan Khatm Alqur'an. Lomba berjenis kaligrafi, seperti menulis naskah, dekorasi, hiasan mushaf, dan illuminasi termasuk di dalamnya. ${ }^{29}$

Lebih dari itu, antusiasme dari banyak kalangan juga turut datang memberikan sponsor. Para sponsor tertarik untuk turut andil memberikan dukungan datang dari institusi, asosiasi, perusahaan, maupun pribadi. Seperti, Radio Republik Indonesia (RRI) mengadakan kontes yang sering disebut dengan pekan tilawati Alqur'an, yang pemenangnya akan dikirim ke Jakarta untuk diikutkan lomba dalam skala yang lebih besar. Ada juga lomba tilawati Alqur'an tingkat SLTP dan SLTA yang diadakan untuk memperingati Hari Pendidikan Nasional. Ada juga beberapa perusahan negara yang turut mengadakan perlombaan atau memberikan sponsor, seperti Pertamina, Telkom, Bank, Hotel, dan sebagainya. ${ }^{30}$

\section{Mood' untuk Kebangkitan}

Anna Gade menyatakan bahwa fenomena seperti tergambar di atas, merupakan aspek perasaan yang menonjol dalam ritual pembelajaran yang terus-menerus dilakukan peningkatan dari perlombaan di dalam sebuah skala kolektif. Sedangkan standarisasi (model bacaan Misri ataupun lainnya) yang diaplikasikan dalam pembelajaran, dikembangkan dalam sistem yang diarahkan untuk motivasi keagamaan dan perluasan gerakan revitalisasi agama.

Fenomena ini mengutamakan strategi kesadaran diri dalam hubungannya dengan Alqur'an untuk merubah sistem sosial. Sebuah

${ }^{29}$ Perlomban ini di adakan pada tahun 1997. Lihat. Anna M. Gade, Perfection Makes Practice, 230.

30 Selengkapnya lihat. Anna M. Gade, Perfection Makes Practice, 231. Selain mensponsori kegiatan tersebut, Anna juga menyebutkan bahwa Telkom juga mensponsori kegiatan perlombaan pidato, yang mengusung tema "belief, sport, and cultur" (keyakinan, olahraga, dan kebudayaan). 
sistem baru (model mijawwad), muncul sebagai model pendidikan yang digambarkan oleh para praktisi dalam upaya mencapai standar tinggi dari tehnik karya seni. Kompetensi dalam gaya pembacaan ini semakin umum di Indonesia, terutama dalam dekade awal pelaksanaan yang sebagian besar dipengaruhi kompetisi (ada tujuh (7) jenis lagu yang dipakai standar pada tahun 1977). Hal ini membuktikan bahwa semakin banyak masyarakat yang tertarik untuk memenuhi perintah agama, membaca Alqur'an dengan cara yang 'indah'.

Tilawab dengan cara mijawwad telah diidentifikasi sebagai model bacaan yang ideal dan terkenal di kalangan para qari' asal Timur Tengah, dan secara luas dipahami sebagai model praktik yang telah membiasa sehingga menjadi 'kurikulum' pembacaan Alqur'an di Indonesia. Selain itu, muncul juga formalisasi pendidik yang bertujuan membangun jenis keahlian. Sehingga ada prosedur yang harus dicapai (sering kali dalam orthopraxy), yaitu aspek fleksibelitas dan norma keindahan, tapi dengan tetap mempertimbangkan aspek tehnik yang efektif, rasa, kontrol, dan spontanitas. Inilah normatifitas dengan standar yang fleksibel, dan telah diterima di Indonesia sebagai tatacara untuk praktek pembacaan Alqur'an. ${ }^{31}$

\section{Penutup}

Dalam konteks ini, Anna Gade melakukan kajian dengan pendekatan antropologis dengan mengadopsi teori Geertz. Titik tekannya terletak pada pencarian ide-ide atau simbol-simbol dalam fenomena yang terjadi di masyarakat muslim Indonesia, khususnya di Sulawesi Selatan. Selain itu Anna Gade juga berupaya mengungkap moods and motivations (perasaan dan motivasi) yang kuat dibalik simbol-simbol tersebut, yang mendorong seseorang untuk tetap melakukan dan senantiasa melestarikannya.

Setidaknya ada tiga aspek yang terungkap di sini, yaitu aspek doktrin ijaz, yang menganggap mushaf Alqur'an telah final dan merupakan

${ }^{31}$ Anna M. Gade, Perfection Makes Practice, 269. 
sebuah mu'jizat yang harus dibaca apa adanya (sesuai yang tertera dalam mushaf). Namun untuk praktek pembacaan dan proses pembelajarannya, sangat terbuka untuk dilakukan pengembangan, terutama dalam hal model bacaan dalam ragam keindahannya. Kedua aspek tersebut saling terkait sehingga berpengaruh terhadap status sosial (baik dalam proses pembelajaran dan pelantunannya), sehingga lahirlah kompetisi-kompetisi pembacaan Alqur'an (MTQ). Dalam kenyataanya, MTQ sendiri mengalami perkembangan yang cukup signifikan, bahkan sangat berpengaruh dalam menumbuhkan minat belajar Alqur'an. Di sini, Anna Gade menunjukkan bahwa upaya menghidupkan Alqur'an oleh masyarakat muslim Indonesia sangatlah tinggi. Alqur'an tidak hanya dibaca dan ditulis indah (resepsi estetis), namun ada proses pergumulan budaya (cultural), dan upaya untuk menafsirkan, seperti dalam perlombaan tafsir (hermenutis).

\section{Referensi}

Azra, Azyumardi. Jaringan Ulama Timur Tengah dan Kepulauan Nusantara Abad XVII dan XVIII. Bandung: Mizan, 1998.

Gade, Anna M. Perfection Makes Practice; Lerning, Emotion, and The Recited Qur'an in Indonesia. USA: Hawai Press, 2004.

Connolly, Peter. (ed.). Aneka Pendekatan Studi Agama, terj. Imam Khoiri. Yogyakarta: LKiS, 2012

Clifford, Geertz. "Agama Sebagai Sistem kebudayaan”, dalam Daniel L. Pals (ed.), Seven Theories of Religion, terj. Inya Indza Mundzier. Yogyakarta: IRCiSod, t.th.

Iskandar, Syahrullah. MTQ dan Negara; Sebuah Tinjauan Hegemonik, dalam Irwan Abdullah, dkk. (ed.), Dialektika Teks Suci Agama. Yogyakarta: Sekolah Pasca Sarjana UGM, 2008.

Koentjaraningrat. Pengantar Ilmu Antroplogi. Jakarta: Rineka Cipta, 2009.

Mansyur, M. dkk. Metodologi Penelitan Living Qur'an dan Hadith. Yogyakarta: TH Press, 2007. 
Mustaqim, Abdul. "Metode Penelitian Living Qur'an; Model Penelitian Kualitatif", dalam M. Mansur, dkk., Metodologi Penelitian Living Qur'an dan Hadith. Yogyakarta: Teras, 2007.

Rasmussen, Anne. Women, The Recited Qur'an, and Islamic Music in Indonesia. London: University of California, 2010.

Salimudin, Fenomena Seni Baca Al-Qur'an; catatan Anna Rasmussen, Makalah tidak diterbitkan.

Setiawan, Nur Kholis. "Orientalisme Al-Qur'an: Dulu, Kini dan Masa Datang", dalam Sahiron Syamsuddin dan Nur Kholis Setiawan (ed.). Orientalisme Alqur'an dan Hadith. Yogyakarta: Nawesea Press, 2007.

Shihab, M. Quraish. Membumikan Al-Qur'an. Bandung: Mizan, 2007.

Syamsuddin, Sahiron, "Pendekatan Orientalis dalam Studi Al-Qur'an", dalam Moch Nur Ichwan dan Ahmad Muttaqien. Islam, Agamaagama dan Nilai Kemanusiaan; Festschrift untuk. Amin Abdullah. Yogyakarta: CISForm, 2013.

Thamrin, M. Husni. Nagham dalam Al-Qur'an: Telaah atas Kemunculan dan Perkembangan Nagham di Indonesia, Yogyakarta: Tesis UIN Sunan Kalijaga, 2008.

http://id.wikipedia.org/

www.islamicstudies.harvard.edu.

sites.google.com/a/wisc.edu/amgade. 